\title{
Paleocene plastic clay from the Vejle Fjord area
}

\author{
CLAUS HEILMANN-CLAUSEN
}

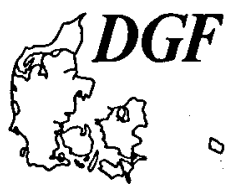

Heilmann-Clausen, C.: Paleocene plastic clay from the Vejle Fjord area. Bull. geol. Soc. Denmark, vol.

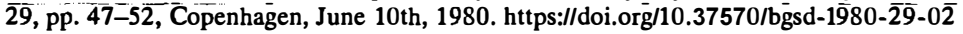

Dinoflagellate analyses indicate a Thanetian age (Deflandrea speciosa zone) for part of the plastic clays exposed in the Vejle Fjord area. The clays are compared with similar Paleocene sediments from several borings in Denmark. The gray, non-calcareous clay at StolleKlint, Fur, is correlated with the lower part of the ash-bearing series.

Claus Heilmann-Clausen, Palaoøkologisk Afdeling, Institut for Genetik og Økologi, Aarhus Universitet, 8000 Arhus C, Denmark. December 17th, 1979.

\section{Introduction}

The Lower Tertiary so-called plastic clays from the Danish area comprise a series of extremely fine grained marine clays which show a variety of colours. The best known of these sediments are the Røsnæs Clay, the Lillebælt Clay and the Søvind Marl (Sorgenfrei 1957; Dinesen, Michelsen \& Lieberkind 1977). They are exposed at several localities and their Eocene age is firmly established from both biostratigraphical evidence and from their lithostratigraphical position above the Upper Paleocene/Lower Eocene (Hansen 1979) ash-bearing series known as the Mo Clay Formation and the time equivalent Clay with Tuff Formation.

However, lithostratigraphical data from several widespread borings in Denmark indicate that lithologically similar clays were deposited in parts of the Danish area earlier than the ash-bearing series, i.e. in the Paleocene (Andersen 1944: 419; Dinesen et al. 1977). No biostratigraphical dating of these sediments has so far been carried out, and until recently the occurrence of Paleocene plastic clay has not been reported with certainty from surface exposures.

This paper presents a biostratigraphical analysis of outcrops in the Vejle Fjord area (fig. 1 ), showing that part of the plastic clays is of Paleocene age.

\section{Exposures and lithology}

The exposures of Paleocene plastic clay are found near Albækhoved and on the island of Ebelø (fig. 1). In a coastal cliff $850 \mathrm{~m}$ east of Albækhoved about $3 \mathrm{~m}$ of plastic clay are exposed below an approximately $1.5 \mathrm{~m}$ thick sequence of the ash-bearing series. The contact between the clay and the ash-bearing series is glacio-tectonic, and only the uppermost part of the ash series is present. The ash-bearing series from this locality has been described by Andersen (1937).

The clay below the ash-bearing series is slightly calcareous, very fine-grained, and sticky. The clay is bioturbated and without distinct bedding. The lowermost $1 \mathrm{~m}$ of the clay is dark blue-green and contains well preserved dinoflagellate cysts. The upper $2 \mathrm{~m}$ are dark red-brown and samples from this part were barren of palynomorphs.

On Fbelø clays of similar lithology are exposed in a very low cliff on the southwest coast about $150 \mathrm{~m}$ north of the abandoned boat harbour. The small disturbed outcrop includes a 1.1 $\mathrm{m}$ thick sequence of plastic clay. The lowermost $80 \mathrm{~cm}$ of the clay is gray-green, the upper $30 \mathrm{~cm}$ of the clay is red-brown. Above the red-brown clay is a Quarternary glacial moraine (Flemming Gersner, pers. comm.). Similar to the section at Albækhoved, the greenish clay contains well preserved dinoflagellate cysts, while a sample of the red-brown clay was barren.

\section{Dinoflagellate analysis}

A sample of dark blue-green clay from Albækhoved and a sample of gray-green clay from Fbelø yielded very similar assemblages of dinoflagellate cysts. The following species occur in both samples: 


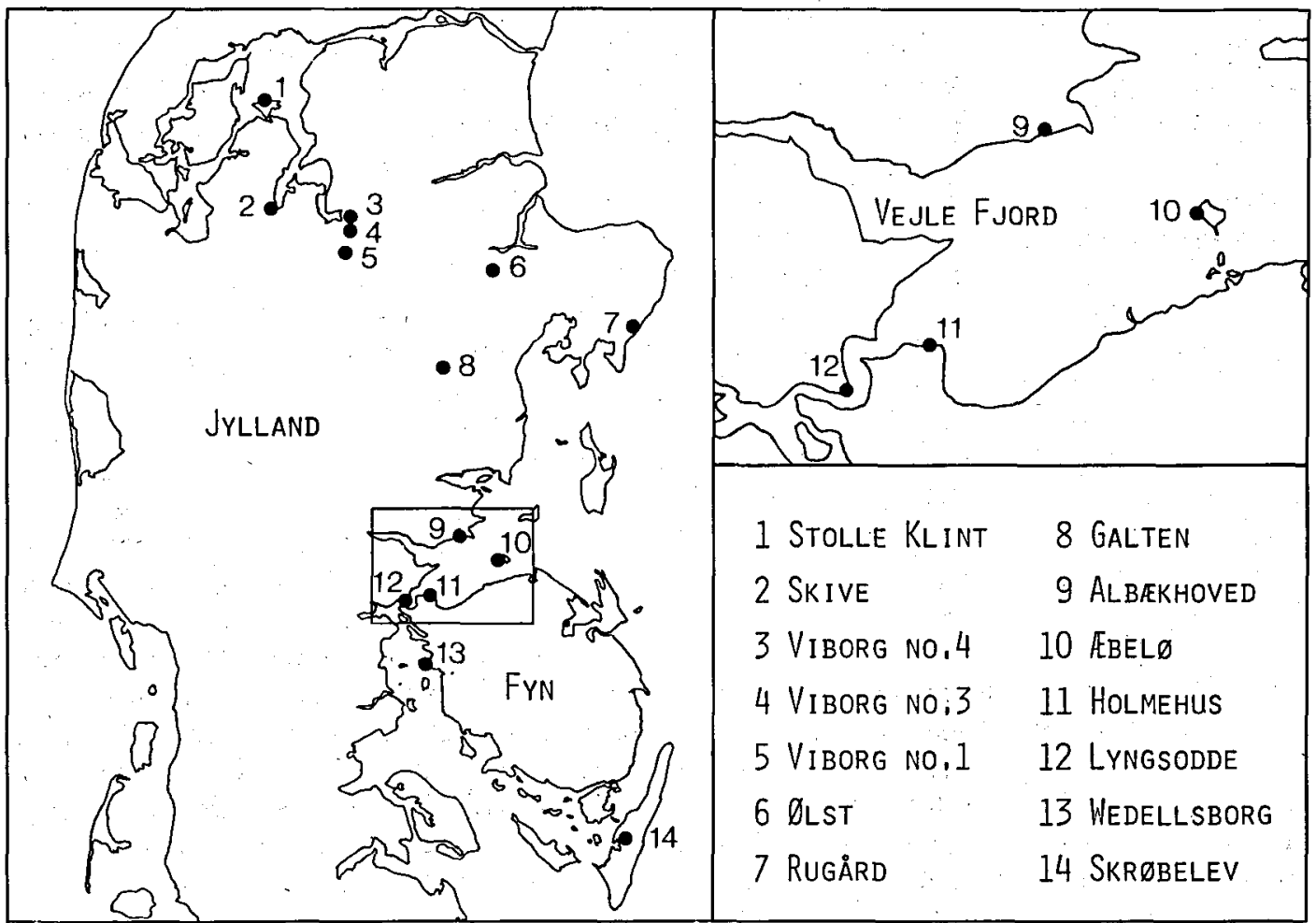

Fig. 1. Map showing localities referred to in the text.

Areoligera senonensis, Deflandrea speciosa, Hystrichokolpoma aff. mentitum, Hystrichosphaeridium tubiferum, Achomosphaera alcicornu, Thalassiphora delicata, Cordosphaeridium inodes and Cordosphaeridium aff. exilimurum:

In both samples the total number of these taxa accounts for about $75 \%$ of the total assemblage. Areoligera senonensis alone makes up 55-60\% of the total assemblage. Species of Spiniferites and Achomosphaera account for most of the remaining part of the assemblage.

The dinoflagellate assemblage indicates a Thanetian age, specifically the Deflandrea speciosa zone (Caro 1973; Caro, Luterbacher, Perch-Nielsen, Premoli-Silva, Riedel \& Sanfilippo 1975; Hansen in prep.). The lower part of the ash-bearing series belongs to the younger Apectodinium hyperacanthum zone (Hansen 1979). The plastic clay investigated here is therefore older than the ash-bearing series.

\section{Discussion}

Data from borings show that plastic clay occurs below the ash-bearing series at several different localities in Denmark. Gry (1935) mentions plastic clay below the ash-bearing series from borings at Skrøbelev, Wedellsborg, Galten and Skive (fig. 1). Flagler (1940) mentions green and light brownish, very poorly bedded, mainly non-calcareous clays from the Paleocene of the Viborg borings Nos. 1, 3 and 4. In Viborg boring No. 4 the plastic clay occurs immediately below the ash-bearing series. According to Flagler (1940) the lower part of the ash-bearing series is composed of laminated, dark gray shales, and the contact to the plastic clay below is sharp. In Viborg borings Nos. 1 and 3 dark gray, poorly bedded clay, grading downwards into green and brownish clays, has a sharp contact to the laminated ash-bearing series above. 
Based solely on the lithological evidence Flagler (1940) claims that an erosional surface and a low angular unconformity is present between the poorly bedded clays and the laminated ash-bearing series. A hiatus below the ash-bearing series in large parts of the North Sea area, including Denmark, has recently been suggested by Knox \& Harland (1979). Unfortunately the cores of the Viborg borings appear to be the only undisturbed samples of this contact in the Danish area.

The laminated, dark gray shales that according to Flagler (1940) form the lower part of the ash-bearing series in the Viborg borings can probably be correlated with the gray clay exposed below the Mo Clay at Stolle Klint, Fur (fig. 1). This clay has been correlated by Dinesen et al. (1977) with Paleocene gray clays (unnamed formation) above the Kerteminde Marl, known from a previous exposure at Rugård (fig. 1) and from borings. Recent observations of the exposure at Stolle Klint show that the sediment is finely laminated, olive black, silty, non-calcareous clay. This lithology fits well with the laminated shales in the lower part of the ash-bearing series in the Viborg borings, as described by Flagler (1940). Very similar laminated clays form the lower part of the ash-bearing series in Ølst quarry (fig. 1).

The sediment from Rugård belongs to the $D e$ flandrea speciosa zone (Hansen in prep.) whereas the clay at Stolle Klint (as well as the lower part of the ash-bearing series) belongs to the Apectodinium hyperacanthum zone (Hansen 1979). Both lithostratigraphy and biostratigraphy therefore support a correlation of the clay at Stolle Klint with the lower part of the ash-bearing series as defined by Flagler (1940).

From a boring (LB 38) at Lyngsodde (fig. 1) Dinesen et al. (1977) described a $12 \mathrm{~m}$ thick sequence of greenish and red-brown sticky plastic clay found below the ash-bearing series. They correlate this sequence with the Paleocene plastic clay found in the other borings mentioned above and tentatively term it the "Holmehus Clay". This name was chosen after an outcrop of possible Paleocene plastic clay at Holmehus (fig. 1) mentioned briefly by Bøggild (1918: 77). This is the only previous report of possible Paleocene plastic clay from outcrops in Denmark: However, the name cannot be recommended since the plastic clay at Holmehus has not been shown to be
Paleocene and because the outcrop no longer exists. Furthermore, the name was previously suggested by Ravn (1906) for the Lower Eocene part of the plastic clays that outcrop in the Holmehus area.

\section{Systematic remarks}

Hystrichokolpoma aff. mentitum McLean, 1974. Dimensions (mean of 11 specimens measured): Total LxB: $53 \mu \mathrm{m} \times 56 \mu \mathrm{m}$. Central body LxB: $41 \mu \mathrm{m} \times 41 \mu \mathrm{m}$. (Measured on specimens with detached operculum).

$H$. aff. mentitum differs from $H$. mentitum McLean, 1974 by sculpture of the endophragm and in process morphology. A distinct reticulum is developed in the relatively wide pandasutural areas between processes and on endophragm below processes. The reticulum consists of large (up to $4 \mu \mathrm{m}$ wide) luminae with irregular rounded outlines. Muri between luminae and narrow zones around process bases are punctate. Punctae are not observed below processes and probably derive from periphragm.

$\mathrm{U}$ - shaped partitions in the postcingular processes, as described for $H$. mentitum McLean, 1974 are not observed in $H$. aff. mentitum. Furthermore $H$. aff. mentitum differs in having distally open processes.

H. aff. mentitum differs from Alisocysta margarita (Harland) Harland, 1979 in being larger (dimensions of central body is comparable to total dimensions in A. margarita). Also the ratio process length: diameter of central body is larger in $H$. aff. mentitum. The thickenings of periphragm on processes and process bases mentioned for $A$. margarita have not been observed in $H$. aff. mentitum.

However, the species discussed above are closely related in general morphology and in paratabulation. The development of the parasulcal area, with 4 small processes invariably present, in particular indicates a close relationship. As mentioned by Harland (1979) $\mathrm{H}$. mentitum and $A$. margarita may be within the morphological range of one species.

Cordosphaeridium aff. exilimurum Davey \& Williams, 1966. Dimensions (mean of 3 specimens measured): Total LxB: $108 \mu \mathrm{m} \times 95 \mu \mathrm{m}$. Central body LxB: $67 \mu \mathrm{m} \times 60 \mu \mathrm{m}$. 
A。

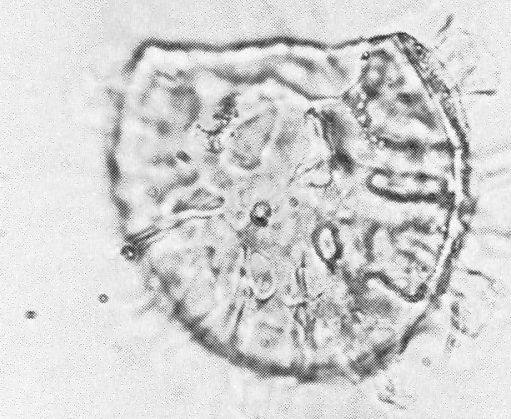

B.

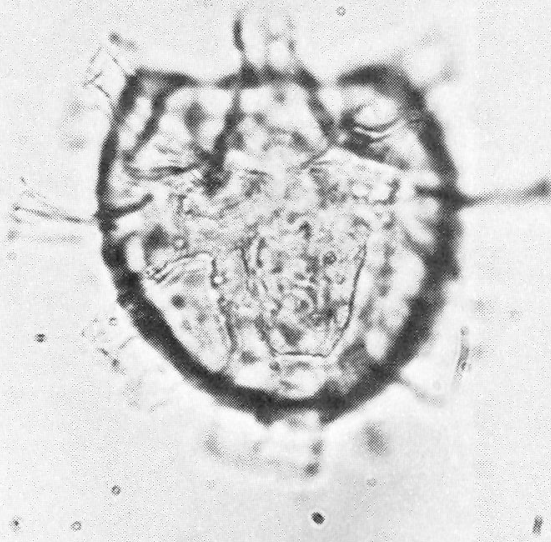

Fig. 2. Hystrichokokolpoma aff. mentitum. Sample 130. Loc. AEbelø. Large specimen. A: Ventral view of ventral side. B: Ventral view of dorsal side. $768 \times$.

A

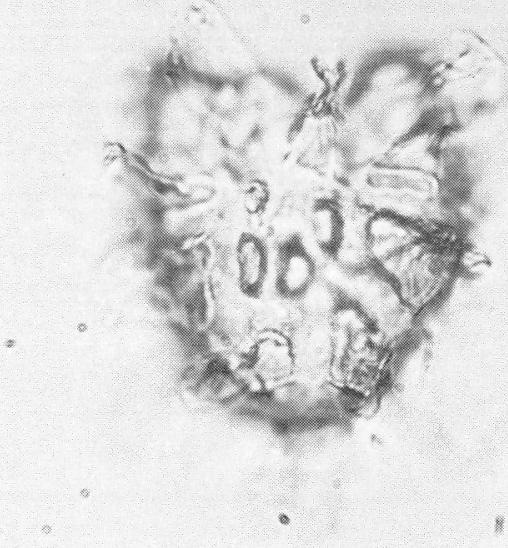

B.

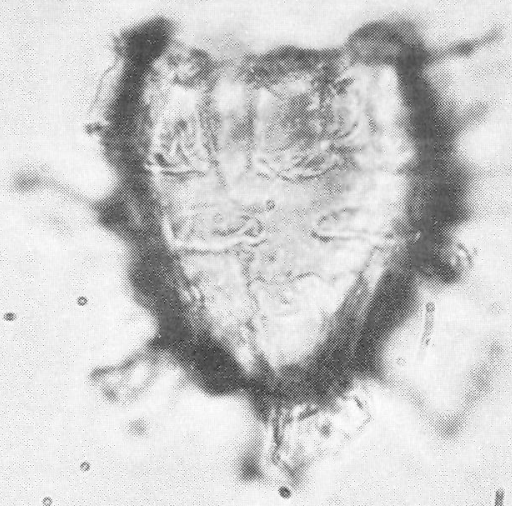

Fig. 3. Hystrichokolpoma aff. mentitum. Sample 127. Loc. Albakhoved. Small specimen. A: Ventral view of ventral side. B: Ventral view of dorsal side. $960 \times$. 


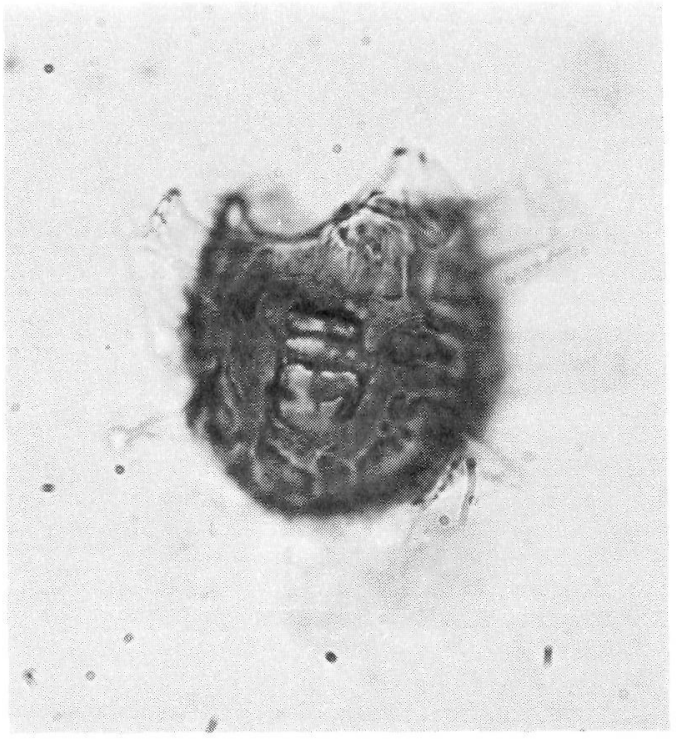

Fig. 4. Hystrichokolpoma aff. mentitum. Sample 127. Loc. Albakhoved. Specimen showing distinct sculpture. Left view of left side. The bases of the processes $l c$ and $2^{\prime \prime \prime}$ are visible near the centre. $768 \times$.

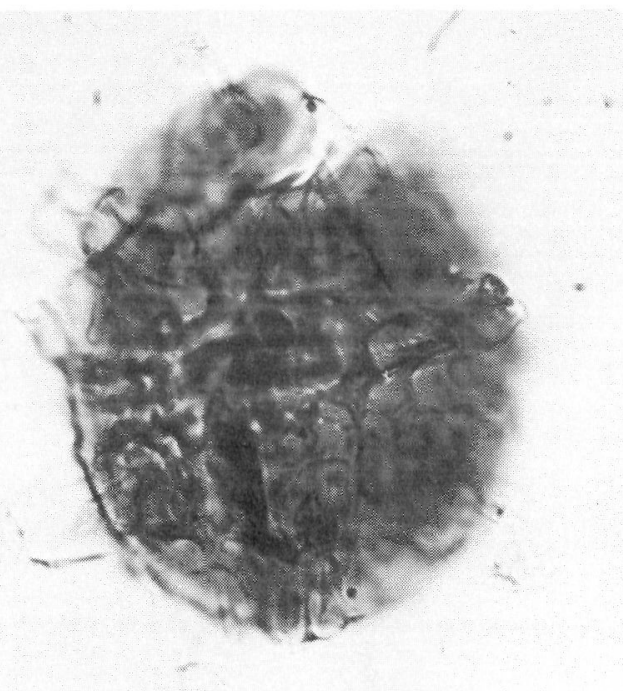

Fig. 6. Hystrichokolpoma aff. mentitum. Sample 127. Loc. Albakhoved. Specimen showing distinct sculpture and very thin hyaline processes. $960 \times$.

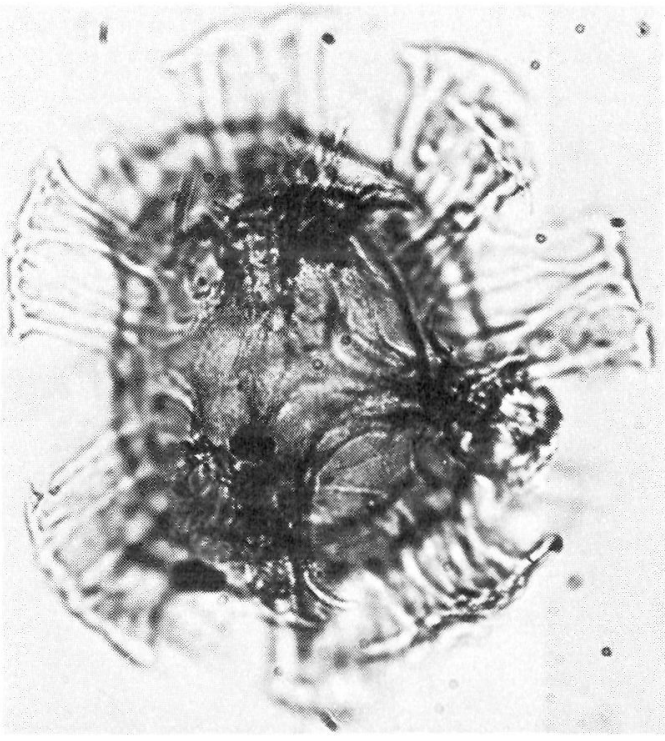

Fig. 5. Cordosphaeridium aff. exilimurum. Sample 127. Loc. Albakhoved. Specimen showing morphology of processes. 605 $\times$.

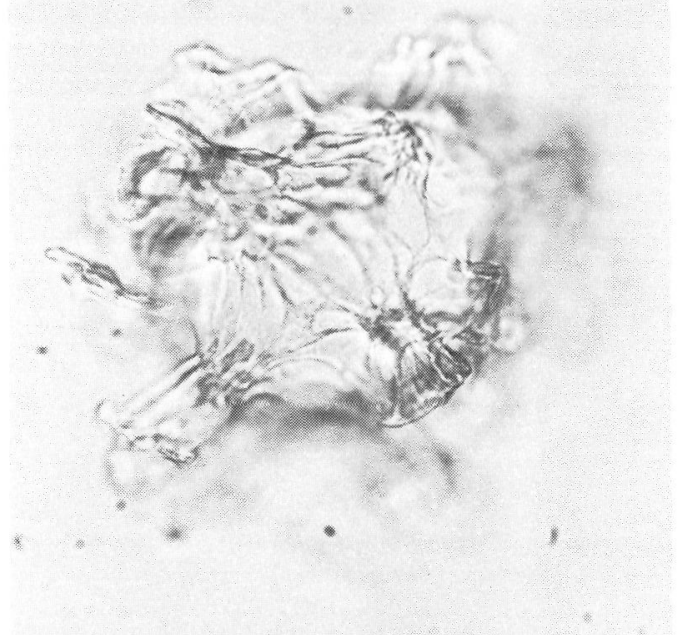

Fig. 7. Cordosphaeridium aff. exilimurum. Sample 127 Loc. Albcekhoved. Specimen showing sculpture of periphragm. 605 $\times$. 
C. aff. exilimurum differs from $C$. exilimurum Davey \& Williams, 1966 in the following characters:

The wall of the central body is thicker, $1.5-2$ $\mu \mathrm{m}$ thick in $C$. aff. exilimurum. The sculpture of the periphragm is more distinct. Widely spaced fibrils radiate from the process bases over the surface of the central body, joining together with similar fibrils from neighbouring processes, and forming a very open reticulum. The wide processes are fibrous and fenestrate. Distally they are moderately expanded.

Acknowledgements. Flemming Gersner kindly supplied useful information and provided samples from the Ebelø outcrop. Flemming Gersner, Jens Morten Hansen, Nils Spjeldnæs and Erik Thomsen are thanked for helpful discussions and critical reading of the original manuscript. J. R. Wilson kindly improved the English text.

\section{Dansk sammendrag}

Dinoflagellat analyser viser, at plastisk ler fra to blotninger (nær Albækhoved og på Ebelø, fig. 1) er af Thanetien alder, idet det kan henføres til Deflandrea speciosa zonen. Det er dermed ældre end den Øvre Paleocæne/Nedre Eocæne askeførende serie.

Dette resultat stemmer overens med data fra boringer fra forskellige dele af det danske område, hvor plastisk ler er beskrevet under den askeførende serie.

Det kalkfri, olivensorte, laminerede ler, som kendes fra en blotning ved Stolle Klint på Fur, henføres til den nederste del af den askeførende serie.

\section{References}

Andersen, S. A. 1937: De vulkanske Askelag i Vejgennemskæringen ved Ølst og deres Udbredelse i Danmark. Danmarks geol. Unders. rk. 2, 59: 52 pp.

Andersen, S. A. 1944: Det danske Landskabs Historie ed. 2, 1: 480 pp. Copenhagen: Andersen \& Gøtterups Forlag.

Bøggild, O. B. 1918: Den vulkanske Aske i Moleret samt en Oversigt over Danmarks ældre Tertiærbjergarter. Danmarks geol. Unders. rk. 2, 33: 159 pp.

Caro, Y. 1973: Contribution a la connaissance des dinoflagellés du Paléocene - Éocene inferieur des Pyrenées espagnoles. Rev. Esp. Micropaleont. 5: 329-372.

Caro, Y., Luterbacher, H., Perch-Nielsen, K., Premoli-Silva, I., Riedel, W. R. \& Sanfilippo, A. 1975: Zonations a l'aide de microfossiles pélagiques du Paléocene supérieur et de l'Éocene inférieur. B. S. G. F. ser. 7, 17: 125-147.

Davey, R. J. \& Williams, G. L. 1966: The genus Hystrichosphaeridium and its allies. In Davey, R. J., Downie, C., Sarjeant, W. A. S. \& Williams, G. L.: Studies on Mesozoic and Cainozoic dinoflagellate cysts. Bull. Br. Mus. (nat. Hist.) Geology, suppl. 3: 53-106.

Dinesen, A., Michelsen, O. \& Lieberkind, K. 1977: A survey of the Paleocene and Eocene deposits of Jylland and Fyn. Danmarks geol. Unders. ser. B, 1: 15 pp.

Flagler, C. W. 1940: Report on the stratigraphy and foraminifera of the Viborg core drill profile Mid - Jutland, Denmark. Danish American Prospecting Company, unpubl. report.

Gry, H. 1935: Petrology of the Paleocene Sedimentary Rocks of Denmark. Danmarks geol. Unders. rk. 2, 61: 172 pp.

Hansen, J. M. 1979: Age of the Mo-Clay Formation. Bull. geol. Soc. Denmark 27: 89-91.

Hansen, J. M. in prep: Stratigraphy and structure of the Paleocene in central West Greenland and Denmark.

Harland, R. 1979: Agerasphaera nov. gen., an 'Eisenackia' like dinoflagellate cyst from the Thanet Sands (Paleocene) of southeast England. Rev. Palaeobot. Palynol. 28: 27-35.

Knox, R. W. O'B. \& Harland, R. 1979: Stratigraphical relationships of the early Palaeogene ash - series of NW Europe. J. geol. Soc. London 136: 463-470.

McLean, D. M. 1974: Two new Paleocene dinoflagellates from Virginia and Maryland. Palaeontology 17: 65-70.

Ravn, J. P. J. 1906: Om det såkaldte plastiske Lers Alder. Meddr. dansk geol. Foren. 12: 23-28.

Sorgenfrei, T. 1957: Formations of Denmark. Lexique Stratigraphique International 1 (2d): $44 \mathrm{pp}$. 